\title{
Alopecia Porphyrinica in a Patient with Chronic Hepatitis C
}

\section{Alopécia Porfirínica em Doente com Hepatite C Crónica}

Stepanka BETKOVA ${ }^{1}$, Bruno DUARTE², Ana RODRIGUES ${ }^{2}$

Acta Med Port 2022 Sep;35(9):675-676 - https://doi.org/10.20344/amp.14626

Keywords: Alopecia; Porphyria Cutanea Tarda; Hepatitis C, Chronic

Palavras-chave: Alopecia; Hepatite C Crónica; Porfiria Cutânea Tardia

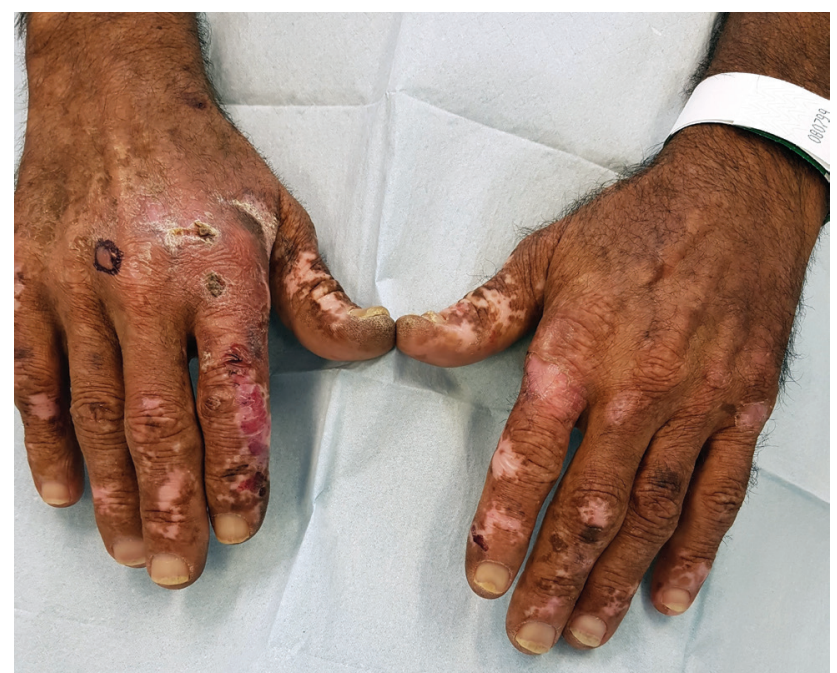

Figure 1 - Serohemorrhagic bullae, erosions and whitish stellate scars on the hands

A 52-year-old homeless man, having a medical history of chronic hepatitis $\mathrm{C}$ virus (HCV) infection and drug abuse, presented with a 10-year history of hair loss and recurrent bullae on the hands and scalp. Physical examination revealed tense serohemorrhagic bullae, erosions and whitish stellate scars (Fig. 1). He also had focal cicatricial alopecia (Fig. 2). Severe facial dermatoheliosis (i.e. a specific dermatological term to describe specific skin changes induced by chronic UV exposure) and hypertrichosis were seen. The histopathology examination of a fresh bullae showed dermal papillae protruding into a subepidermal bulla in a festooned pattern (i.e. a histopathological hallmark presentation of porphyria cutanea tarda. Its presence, albeit not necessary, is strongly suggestive of the diagnosis). High levels of uroporphyrin ( $1843 \mu \mathrm{g} / 24$ hours) and serum ferritin $(1103 \mathrm{ng} / \mathrm{mL}$ ) were present. A diagnosis of porphyria cutanea tarda (PCT) was made. HCV infection was treated with direct-acting antivirals. Topical corticosteroids and regular phlebotomies were offered for PCT, but the patient was lost to follow-up.

PCT is a photosensitive disorder strongly associated with HCV infection. ${ }^{1}$ Scleroderma-like changes are uncom-

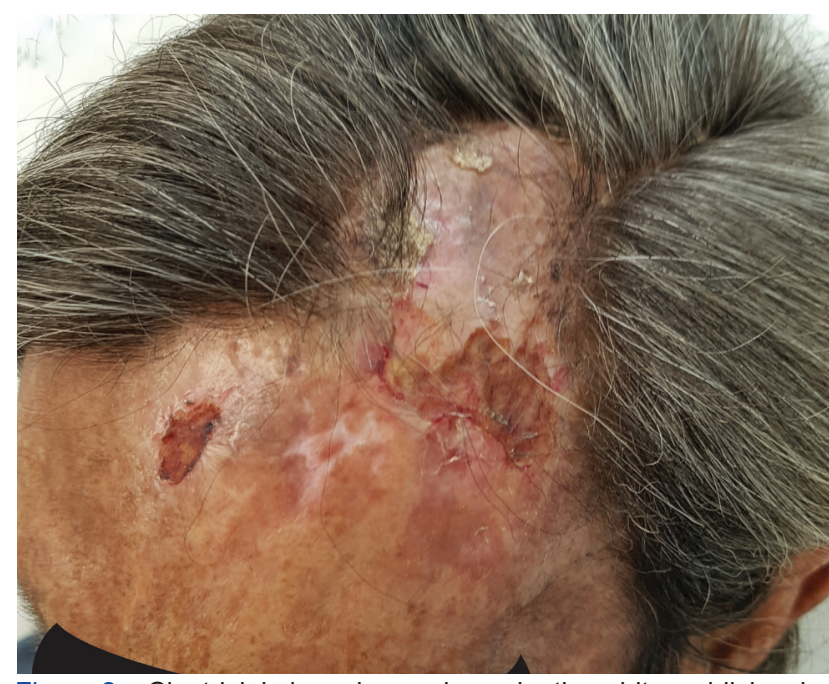

Figure 2 - Cicatricial alopecia, as shown by the white-reddish sclerotic plaque with loss of hair, crusts and depressed scars on the left forehead

monly found $(2 \%-18 \%),{ }^{2}$ but they may present as scarring alopecia, either isolated or as a feature of florid presentations.

\section{AUTHORS CONTRIBUTION}

SB, BD: Case description and discussion.

AR: Critical review of the work.

\section{PROTECTION OF HUMANS AND ANIMALS}

The authors declare that the procedures were followed according to the regulations established by the Clinical Research and Ethics Committee and to the Helsinki Declaration of the World Medical Association updated in 2013.

\section{DATA CONFIDENTIALITY}

The authors declare having followed the protocols in use at their working center regarding patients' data publication.

\section{INFORMED CONSENT \\ Obtained.}

\footnotetext{
1. Infectious Diseases Department. Hospital Curry Cabral. Centro Hospitalar Universitário Lisboa Central. Lisboa. Portugal.

2. Dermatology and Venereology Department. Hospital de Santo António dos Capuchos. Centro Hospitalar Universitário Lisboa Central. Lisboa. Portugal. $\square$ Autor correspondente: Stepanka Betkova. stepanka.betkova@gmail.com

Recebido/Received: 24/07/2020 - Aceite/Accepted: 16/07/2021 - Publicado Online/Published Online: 22/09/2021 - Publicado/Published: 01/09/2022 Copyright @ Ordem dos Médicos 2022
} 


\section{COMPETING INTERESTS}

The authors declare that there are no competing interests.

\section{REFERENCES}

1. Chan CC, Lin SJ. Porphyria cutanea tarda. N Engl J Med. 2011;365:1128.

2. Volksbeck S, Nashan D, Bruckner-Tuderman L, Braun-Falco M. Localized sclerosis of the scalp (alopecia porphyrinica) as predominant

\section{FUNDING SOURCES}

The authors declare that there were no external sources of study for the performance of this article.

presentation of porphyria cutanea tarda. J Eur Acad Dermatol Venereol. 2007;21:1125-7. 